\title{
In Vitro and In Vivo Assessment of Targeting Lipid-based Nanoparticles to the Epidermal Growth Factor-Receptor (EGFR) Using a Novel Heptameric ZEGFr Domain
}

\author{
S. Rahima Benhabbour ${ }^{\mathrm{a}}$, J. Christopher Luft ${ }^{\mathrm{c}}$, Dongwook Kim ${ }^{\mathrm{d}}$, Anekant Jain ${ }^{\mathrm{a}}$, Saurabh \\ Wadhwa ${ }^{a}$, Matthew C. Parrott ${ }^{c}$, Rihe Liub,d,e, Joseph DeSimone ${ }^{b, c}$, and Russell J. \\ Mumpera,b, ${ }^{,}$ \\ ${ }^{a}$ Center for Nanotechnology in Drug Delivery, Division of Molecular Pharmaceutics, UNC \\ Eshelman School of Pharmacy \\ bUNC Lineberger Comprehensive Cancer Center, University of North Carolina at Chapel Hill, \\ North Carolina \\ 'Department of Chemistry, University of North Carolina at Chapel Hill, North Carolina \\ ${ }^{d}$ Division of Medicinal Chemistry and Natural Products, UNC Eshelman School of Pharmacy, \\ University of North Carolina at Chapel Hill, North Carolina \\ eCarolina Center for Genome Sciences, University of North Carolina at Chapel Hill, North \\ Carolina
}

\section{Abstract}

Lipid-based oil-filled nanoparticles (NPs) with a high concentration of surface-chelated nickel (Ni-NPs) were successfully prepared using a Brij78-NTA-Ni conjugate synthesized with Brij 78 (Polyoxyethylene (20) stearyl ether) and nitrilotriacetic acid (NTA). The facile incorporation of the Brij 78-NTA-Ni conjugate into the NP formulation allowed up to $90 \% \mathrm{Ni}$ incorporation, which was a significant improvement over the previously used standard agent DOGS-NTA-Ni which led to $\sim 6 \% \mathrm{Ni}$ incorporation. The Ni-NPs were targeted to the highly epidermal growth factor receptor (EGFR)-overexpressing epidermoid carcinoma cells A431. This was accomplished using a novel high affinity histidine $\times 6$-tagged EGFR-binding $\mathrm{Z}$ domain (heptameric $\mathrm{Z}^{\mathrm{EGFR}}$ domain). In vitro cell uptake studies showed enhanced internalization (up to 90\%) of the targeted Ni-NPs in A431 cells with only $\leq 10 \%$ internalization of the of untargeted Ni-NPs. ICP-MS analysis used to quantify the amount of $\mathrm{Ni}$ in the cells were in close agreement with flow cytometry studies, which showed a dose dependent increase in the amount of Ni with the targeted Ni-NPs. Cell uptake competition studies showed that internalization of the targeted Ni-NPs within the cells was competed off with free heptameric $\mathrm{Z}^{\mathrm{EGFR}}$ domain at concentrations of $8.75 \mathrm{ng} / \mathrm{mL}$ or higher. In vivo studies were carried out in nude mice bearing A431 tumors to determine the biodistribution and intracellular delivery. Near Infrared (NIR) optical imaging studies using Alexa750-labeled heptameric $\mathrm{Z}^{\mathrm{EGFR}}$ domain showed localization of $19 \%$ of the total detected fluorescence intensity in the tumor tissue, $28 \%$ in the liver and $42 \%$ in the kidneys $16 \mathrm{~h}$ post i.v. injection. ICP-MS

() 2011 Elsevier B.V. All rights reserved.

"Corresponding Author: Russell J. Mumper, Ph.D., John A. McNeill Distinguished Professor, Director, Center for Nanotechnology in Drug Delivery, UNC Eshelman School of Pharmacy, University of North Carolina at Chapel Hill, CB 7355, 100G Beard Hall, Chapel Hill, North Carolina 27599-7355, mumper@email.unc.edu, Phone: (919) 966-1271, Fax: (919) 966-6919.

Publisher's Disclaimer: This is a PDF file of an unedited manuscript that has been accepted for publication. As a service to our customers we are providing this early version of the manuscript. The manuscript will undergo copyediting, typesetting, and review of the resulting proof before it is published in its final citable form. Please note that during the production process errors may be discovered which could affect the content, and all legal disclaimers that apply to the journal pertain. 
analysis showed almost a two-fold increase in the amount of intracellular $\mathrm{Ni}$ with the targeted $\mathrm{Ni}$ NPs. These new Ni-NPs could be a very useful tool for targeting and drug delivery to a wide range of EGFR positive cancers.

\section{Keywords}

lipid-based nanoparticles; nickel; histidine-tagged proteins; EGFR targeting; heptameric Z EGFR domain

\section{Introduction}

One of the major requirements for a successful cancer therapeutic is the ability to selectively kill cancer cells with minimal damage to healthy tissue. Selective delivery of chemotherapeutics to cancer cells is an approach known as molecular targeted therapy. This technique is currently combined with chemotherapy and has the potential to replace it in the future.[1] The principle behind targeted therapy is to utilize molecules that interfere with the development and growth of cancer. Amongst these molecules, the human epidermal growth factor receptor (EGFR) has emerged as an attractive target for cancer therapy. The EGFR is a transmembrane tyrosine kinase receptor that regulates important cellular processes such as cell proliferation, apoptosis, differentiation and migration.[2] Overexpression of EGFR has been detected in a wide range of cancers including breast, ovarian, bladder, head and neck, glioma, pancreatic, kidney, lung and prostate, making it an attractive target for both therapeutic and diagnostic applications.[3-5] In the past decade, several EGFR-targeted anticancer therapeutics have been developed using either monoclonal antibodies (MAbs; cetuximab,[6] panitumumab[7]) or tyrosine kinase inhibitors (TKIs; gefitinib[8], erlotinib[9], lapatinib[10]) to block uncontrolled EGFR-mediated signaling.[11-13] More recently, a new class of affinity proteins known as affibody molecules have been introduced as an alternative approach to antibodies for EGFR-targeted systems.[14, 15] Affibodies are comprised of 58 amino acid residues bundled in a three-helix scaffold, a structure derived from the Z-domain of staphylococcal protein A.[16] Additionally, affibody molecules are small $(\sim 7 \mathrm{kDa})$ and are easy to produce by recombinant production in bacteria or by chemical synthesis.[17] Moreover, these proteins have a very high affinity for different receptors including EGFR, HER2, HER3 and HER4.[18, 19] Affibody proteins have been extensively investigated as in vivo imaging agents because of their relatively small size, their ability to exhibit fast tumor targeting, high tumor uptake, and quick clearance from normal tissue.[20-22] In addition, their high binding affinity to EGFR makes them a very appealing targeting ligand for the delivery of therapeutic agents to a wide range of EGFRoverexpressing cancer cells.[23]

To further enhance the binding efficiency, Liu et al. generated a heptameric EGFR-binding targeting ligand, by fusing a heptamerization domain with an EGFR-binding $\mathrm{Z}$ domain. The resulting heptameric targeting ligand is highly stable, can withstand SDS denaturing and binds to EGFR-expressing cancer cells with a significantly improved binding affinity. In vitro cell binding studies showed that as low as $0.1 \mathrm{nM}$ of heptameric $\mathrm{Z}^{\mathrm{EGFR}}(125 \mathrm{kDa})$ bound to EGFR-positive A431 cells tightly and specifically, whereas more than $100 \mathrm{nM}$ monomeric $\mathrm{Z}^{\mathrm{EGFR}}(18 \mathrm{kDa}$ ) was required to achieve similar results (unpublished results).

The targeting ligand can be terminated with a histidine $\times 6$-tag for site-specific attachment to various drug delivery systems such as liposomes and nanoparticles via his-tag-Ni affinity binding.[24] This approach has several advantages over the use of covalent linkages including, facile attachment, mild conditions and the ability to achieve site specific and oriented attachment and high coupling efficiencies.[25-27] 
In the present studies, the surface of Ni-loaded NPs was decorated with a his $\times 6$-tagged heptameric $Z^{\mathrm{EGFR}}$ domain to target EGFR-overexpressing human epidermoid carcinoma A431 cells. In order to achieve tight association between the his $\times 6$-tagged protein and the surface of the NPs, two different NTA-derivatized Brij surfactants (Brij 78-NTA and Brij 700-NTA) were synthesized and then used to prepare the lipid-based NPs. The synthesis of the new conjugates was simple and high yielding. Using these new conjugates, a significant increase (>10-fold) in Ni incorporation was achieved compared to previous results using the commercially available DOGS-NTA-Ni.[28] More importantly, the delivery of the EGFRtargeted Ni-NPs using the novel his $\times 6$-tagged heptameric $Z^{\text {EGFR }}$ domain was accomplished in vitro and in vivo in A431 cancer cells. Combined, these results show a great potential for the novel heptameric $\mathrm{Z}^{\mathrm{EGFR}}$ domain as a targeting ligand to facilitate the delivery and accumulation of nanocarriers to various EGFR overexpressing tumor tissues. To our knowledge, this is the first report on the development of Ni-NPs using Brij 78-NTA-Ni conjugate and targeting Ni-NPs to EGFRoverexpressing cells using a novel heptameric $\mathrm{Z}^{\mathrm{EGFR}}$ domain.

\section{Materials and Methods}

\section{Materials}

1.1. Chemicals-Polyoxyethylene (20) stearyl ether (Brij 78) was purchased from Uniqema (Wilmington, DE). D-alpha-tocopheryl polyethylene glycol 1000 succinate (TPGS) was purchased from Eastman Chemicals (Kingsport, TN). Miglyol 812 is a mixed caprylic $\left(\mathrm{C}_{8: 0}\right)$ and capric $\left(\mathrm{C}_{10: 0}\right)$ fatty acid triglyceride and was purchased from Sasol (Witten, Germany). TEMPO free radical (98\%), iodobenzene diacetate (98\%), $\mathrm{N}$ hydroxysuccinimide (NHS) and nitrilotriacetic acid (NTA, 97+\%) were purchased from Sigma Aldrich (Milwakee, MI). 1-(3-dimethylaminopropyl)-3-ethylcarbodiimide hydrochloride (EDC, 98+\%) was purchased from Alfa Aesar (Ward Hill, MA). Nickel chloride hexahydrate was purchased from Fisher Scientific (City, State). Acetonitrile $\left(\mathrm{CH}_{3} \mathrm{~N}\right)$, dichloromethane $\left(\mathrm{CH}_{2} \mathrm{Cl}_{2}\right)$, tetrahydrofuran (THF), ethanol (EtOH), and diethyl ether were purchased from Fisher Scientific.

1.2. Cells-A431 epidermoid carcinoma cells (American Type Culture Collection, Rockville, Maryland) were used as a model cell for their very high levels of epidermal growth factor receptor (EGFR) expression. Prior to cell uptake studies, A431 cells were cultured in Dulbecco's Modified Eagle Medium, high glucose (DMEM, Invitrogen ${ }^{\mathrm{TM}}$, Grand Island, NY, USA) supplemented with 10\% fetal bovine serum (FBS, Mediatech Inc., Manassas, VA, USA) and $1 \%$ penicillin streptomycin solution (Pen Strep, Invitrogen ${ }^{\mathrm{TM}}$, Grand Island, NY, USA) at $37^{\circ} \mathrm{C}$ and $5 \% \mathrm{CO}_{2}$.

1.3. Analysis-Optical microscopy analysis of cells were carried out using a Zeiss Invertoskop 40C Optical Microscope. Cells (10,000 per sample) were analyzed by flow cytometry (CyAn ADP, Dako), for green and red fluorescence. In vivo fluorescence imaging studies were carried out using the IVIS ${ }^{\circledR}$ spectrum (Caliper Life Sciences) with an epiillumination (from the top) capability to illuminate in vivo fluorescent sources.

\subsection{Characterization}

1.4.1. NMR: NMR spectra were measured on Varian $400 \mathrm{MHz}$ spectrometer. ${ }^{1} \mathrm{H}$ spectra were recorded at $400 \mathrm{MHz}$, and ${ }^{13} \mathrm{C}$ NMR spectra were recorded at $100 \mathrm{MHz}$ in $\mathrm{CDCl}_{3}$ or $\mathrm{CD}_{3} \mathrm{OD}$. The non-deuterated solvent signal was used as internal standard for both ${ }^{1} \mathrm{H}$ and ${ }^{13} \mathrm{C}$ spectra. 
1.4.2. ICP-MS: Inductively Coupled Plasma Mass Spectrometry (ICP-MS) experiments were conducted to quantify Ni content within the lipid-based nanoparticles using a Varian 820-ICPMS, Inductively Coupled Plasma Mass Spectrometer. The source had a MicroMist nebulizer, max flow rate of $0.4 \mathrm{~mL} / \mathrm{min}$, for sample introduction into the plasma. Standard plasma conditions (Power $1.4 \mathrm{~kW}$, plasma flow $18.00 \mathrm{~L} / \mathrm{min}$, auxiliary flow $1.80 \mathrm{~L} / \mathrm{min}$, sheath gas flow $0.18 \mathrm{~L} / \mathrm{min}$ and sampling depth $7.5 \mathrm{~mm}$ ) were used. All solutions were prepared using 18 mega ohm de-ionized water (lab supply) and trace metal grade Nitric Acid (Thermo Fisher Scientific Inc.). Instrument conditions were optimized using the autooptimization feature of this instrument. Samples were introduced while setting the peristaltic pump at $3 \mathrm{rpm}$. The spray chamber was cooled to $3^{\circ} \mathrm{C}$. Standards were prepared using ICP standards purchased from Inorganic Ventures, Christiansburg, VA. In all measurements, a 5 ppb solution of Indium was used as internal standard and mixed online with each sample through a tee. Ions In 115 (internal standard), and ${ }^{60} \mathrm{Ni}$ were monitored in a peak hopping mode, using $50000 \mu \mathrm{Sec}$ as dwell time, and measuring 5 replicates of an average of 20 data points. This gave a scan time of $359 \mathrm{msec}$ and replicate time of 7.17 seconds. The $\mathrm{Ni}$ standard curve included 9 to 13 concentration levels in the range of 0.1 to $500 \mathrm{ppb}$. The standard data set was fitted to a linear curve. The coefficient of correlation was 0.999 or higher in each of the several data sets. Percent Error in calculated concentrations was 11\% or lower (in most cases it was less than 5\%). The blank equivalent was less than $0.1 \mathrm{ppb}$. Only the test data greater than three times the blank equivalent (i.e. $0.3 \mathrm{ppb}$ ) were accepted as valid measurement. During the analysis of each test sample, a reference sample was used for validation and comparison of the test results. For quantitation of Ni in the NPs, preparation included removing the water from the NPs and re-suspending them in $2 \% \mathrm{HNO}_{3}$ solution. Cell samples with internalized $\mathrm{Ni}$, from in vitro flow cytometry studies, involved taking a $0.5 \mathrm{~mL}$ of each cell sample and diluting it with $2 \% \mathrm{HNO}_{3}$ to a total volume of 3.0 $\mathrm{mL}$. In the case of in vivo studies, tumor cells were extracted from homogenized tumors, using a digestion mixture (described in section 2.6.1). The final cell pellet from this step was re-suspended in $2 \% \mathrm{HNO}_{3}$ to a total volume of $3.0 \mathrm{~mL}$ for analysis by ICP-MS.

1.4.3. NP characterization: Additional characterization techniques included particle size measurement of the Ni-NPs using a Coulter N4 Plus Sub-Micron Particle Sizer (Coulter Corporation, Miami, FL) at $90^{\circ}$, and zeta potential using a Malvern Zeta Sizer 2000 (Malvern Instruments, Southborough, MA).

\section{Methods}

\subsection{Synthesis}

General procedure for oxidation of Brij 78: Polyoxyl 20-stearyl ether (Brij 78) (MW = $1152 \mathrm{Da})\left(2.01 \mathrm{~g}, 1.74 \times 10^{-3} \mathrm{~mol}, 1\right.$ equiv) was introduced to a round-bottom flask equipped with a magnetic stir bar as a solution in a 1:1 mixture of water/acetonitrile (40 $\mathrm{mL})$. TEMPO free radical $\left(0.05 \mathrm{~g}, 3.47 \times 10^{-4} \mathrm{~mol}, 0.2\right.$ equiv) was added to the solution, followed by iodobenzene diacetate $\left(1.68 \mathrm{~g}, 5.21 \times 10^{-3} \mathrm{~mol}, 3\right.$ equiv). The reaction mixture was stirred at room temperature for $6 \mathrm{~h}$ (or overnight to ensure the reaction went to completion). The mixture was then concentrated to dryness in vacuo and the residue was dissolved in a minimum amount of ethanol. The crude polymer was precipitated in cold diethyl ether, and recovered by filtration through a glass fritted funnel. After drying in vacuo, Brij 78-acid was obtained as a white solid (1.81 g, 90\%). ${ }^{1} \mathrm{H}$ NMR $(400 \mathrm{MHz}$, $\left.\mathrm{CD}_{3} \mathrm{OD}\right): \delta(\mathrm{ppm})=0.9\left(\mathrm{t}, 3 \mathrm{H},-\mathrm{CH}_{3}\left(\mathrm{CH}_{2}\right)_{16}\right), 1.3\left(\mathrm{~s}\right.$-broad, $\left.30 \mathrm{H},-\left(\mathrm{CH}_{2}\right)_{15} \mathrm{CH}_{3}\right), 1.56$ (t, $2 \mathrm{H},-\mathrm{CH}_{2}\left(\mathrm{CH}_{2}\right)_{15} \mathrm{CH}_{3}$ ), $3.46\left(\mathrm{t}, 2 \mathrm{H},-\mathrm{CH}_{2} \mathrm{O}\right.$ ), 3.63 (s-broad, $\left.72 \mathrm{H},-\mathrm{CH}_{2} \mathrm{CH}_{2} \mathrm{O}\right), 4.1(\mathrm{~s}, 2 \mathrm{H}$, $\left.-\mathrm{CH}_{2} \mathrm{CO}_{2} \mathrm{H}\right) .{ }^{13} \mathrm{C} \mathrm{NMR}\left(100 \mathrm{MHz}, \mathrm{CD}_{3} \mathrm{OD}\right): \delta(\mathrm{ppm})=13.1\left(-\mathrm{CH}_{3}\left(\mathrm{CH}_{2}\right)_{15}\right), 22.34$ $\left(-\mathrm{CH}_{2} \mathrm{CH}_{3}\right), 25.83\left(-\mathrm{CH}_{2} \mathrm{CH}_{2} \mathrm{CH}_{3}\right), 29.36\left(-\left(\mathrm{CH}_{2}\right)_{14} \mathrm{CH}_{2} \mathrm{O}\right), 67.98\left(-\mathrm{CH}_{2} \mathrm{CO}_{2} \mathrm{H}\right), 69.78$ $\left(-\mathrm{CH}_{2} \mathrm{O}-\mathrm{CH}_{2} \mathrm{CO}_{2} \mathrm{H}\right), 70.16\left(-\mathrm{CH}_{2} \mathrm{CH}_{2} \mathrm{O}\right), 70.96\left(-\left(\mathrm{CH}_{2}\right)_{16} \mathrm{CH}_{2} \mathrm{O}\right), 172.93\left(-\mathrm{CO}_{2} \mathrm{H}\right)$. 
General procedure for synthesis of Brij 78-NHS active ester: A flame-dried round bottom flask was charged with Brij 78-acid (1.05 g, 9.0 × 10-4 mol, 1 equiv) and dissolved in dry THF (20 ml) under argon. 1-(3-Dimethylaminopropyl)-3-ethylcarbodiimide hydrochloride (EDC) $\left(0.34 \mathrm{~g}, 1.79 \times 10^{-3} \mathrm{~mol}, 2\right.$ equiv) along with $N$-hydroxysuccinimide (NHS) $\left(0.21 \mathrm{~g}, 1.79 \times 10^{-3} \mathrm{~mol}, 2\right.$ equiv) were added and the solution was stirred at room temperature for $12 \mathrm{~h}$. The precipitate was removed by filtration through a fritted funnel, and the filtrate was concentrated by rotary evaporation. The filtered residue was redissolved in a minimum amount of $\mathrm{CH}_{2} \mathrm{Cl}_{2}$ and passed through a fritted funnel to remove any residual precipitate. The filtrate solvent was removed by rotary evaporation to give the desired product as a white solid $(1.03 \mathrm{~g}, 91 \%) .{ }^{1} \mathrm{H}$ NMR $\left(400 \mathrm{MHz}, \mathrm{CDCl}_{3}\right): \delta(\mathrm{ppm})=0.85(\mathrm{t}, 3 \mathrm{H}$, $-\mathrm{CH}_{3}\left(\mathrm{CH}_{2}\right)_{16}$ ), 1.23 (s-broad, 30H, $\left.-\left(\mathrm{CH}_{2}\right)_{15} \mathrm{CH}_{3}\right), 1.54$ (t, $\left.2 \mathrm{H},-\mathrm{CH}_{2}\left(\mathrm{CH}_{2}\right)_{15} \mathrm{CH}_{3}\right), 2.83$ (s, $4 \mathrm{H},-\mathrm{CH}_{2} \mathrm{CON}$ ), 3.42 (t, $2 \mathrm{H},-\mathrm{CH}_{2} \mathrm{O}$ ), 3.62 (s-broad, $72 \mathrm{H},-\mathrm{CH}_{2} \mathrm{CH}_{2} \mathrm{O}$ ), 4.5 (s, $2 \mathrm{H}$, $\left.-\mathrm{CH}_{2} \mathrm{CO}_{2} \mathrm{H}\right) .{ }^{13} \mathrm{C} \mathrm{NMR}\left(100 \mathrm{MHz}, \mathrm{CDCl}_{3}\right): \delta(\mathrm{ppm})=14.08\left(-\mathrm{CH}_{3}\left(\mathrm{CH}_{2}\right)_{15}\right), 22.65$ $\left(-\mathrm{CH}_{2} \mathrm{CH}_{3}\right), 25.42\left(-\mathrm{CH}_{2} \mathrm{CH}_{2} \mathrm{CH}_{3}\right), 26.06\left(-\mathrm{CH}_{2} \mathrm{CON}\right), 29.36\left(-\left(\mathrm{CH}_{2}\right)_{14} \mathrm{CH}_{2} \mathrm{O}\right), 67.98$ $\left(-\mathrm{CH}_{2} \mathrm{CO}_{2} \mathrm{H}\right), 69.78\left(-\mathrm{CH}_{2} \mathrm{O}-\mathrm{CH}_{2} \mathrm{CO}_{2} \mathrm{H}\right), 70.16\left(-\mathrm{CH}_{2} \mathrm{CH}_{2} \mathrm{O}\right), 70.96\left(-\left(\mathrm{CH}_{2}\right)_{16} \mathrm{CH}_{2} \mathrm{O}\right)$, $165.98(-\mathrm{CON}), 168.73\left(-\mathrm{CO}_{2} \mathrm{H}\right)$.

General procedure for the synthesis of Brij 78-NTA conjugate: Brij 78-NHS active ester $\left(0.51 \mathrm{~g}, 4.03 \times 10^{-4} \mathrm{~mol}, 1\right.$ equiv) was introduced to a round-bottom flask equipped with a magnetic stir bar as a solution in a mixture of $\mathrm{CH}_{2} \mathrm{Cl}_{2} / \mathrm{H}_{2} \mathrm{O}(5: 1,20 \mathrm{~mL})$. Nitrilotriacetic acid (NTA) ( $0.13 \mathrm{~g}, 4.83 \times 10^{-4} \mathrm{~mol}, 1.2$ equiv) was added, and the solution was stirred at room temperature overnight. The solvent was removed by rotary evaporation and the solid was dissolved in a minimum amount of $\mathrm{CH}_{2} \mathrm{Cl}_{2}$ to remove the NHS by-product. The solid precipitate was removed by filtration through a fritted funnel and the filtrate solvent was removed by rotary evaporation to give the desired product as a white solid: $0.58 \mathrm{~g}(98 \%) .{ }^{1} \mathrm{H}$ NMR (400 MHz, $\left.\mathrm{CDCl}_{3}\right): \delta(\mathrm{ppm})=0.81\left(\mathrm{t}, 3 \mathrm{H},-\mathrm{CH}_{3}\left(\mathrm{CH}_{2}\right)_{16}\right), 1.18$ (s-broad, 32H, $\left.\left(\mathrm{CH}_{2}\right)_{16} \mathrm{CH}_{3}\right), 2.82\left(\mathrm{~s}, 2 \mathrm{H},-\mathrm{NCH}_{2} \mathrm{CO}_{2} \mathrm{H}\right), 2.91\left(\mathrm{~s}, 2 \mathrm{H},-\mathrm{NCH}_{2} \mathrm{CO}_{2} \mathrm{H}\right), 3.37$ (t, $2 \mathrm{H},-\mathrm{CH}_{2}-$ $\mathrm{NHCOCH}_{2}$ ), 3.57 (s-broad, $\left.72 \mathrm{H},-\mathrm{CH}_{2} \mathrm{CH}_{2} \mathrm{O}\right), 4.08\left(\mathrm{~s}, 2 \mathrm{H},-\mathrm{CH}_{2} \mathrm{CO}_{2} \mathrm{H}\right) .{ }^{13} \mathrm{C}$ NMR $(100$ $\left.\mathrm{MHz}, \mathrm{CDCl}_{3}\right): \delta(\mathrm{ppm})=14.08\left(-\mathrm{CH}_{3}\left(\mathrm{CH}_{2}\right)_{15}\right), 22.65\left(-\mathrm{CH}_{2} \mathrm{CH}_{3}\right), 26.04\left(-\mathrm{CH}_{2} \mathrm{CH}_{2} \mathrm{CH}_{3}\right)$, $26.06\left(-\mathrm{CH}_{2} \mathrm{CON}\right), 29.6\left(-\left(\mathrm{CH}_{2}\right)_{14} \mathrm{CH}_{2} \mathrm{O}\right), 30.3\left(-\mathrm{CH}_{2} \mathrm{CH}_{2} \mathrm{NHCO}\right), 36.7\left(-\mathrm{CH}_{2} \mathrm{NHCO}\right)$, $57.9\left(-\mathrm{NCH}_{2} \mathrm{CO}_{2} \mathrm{H}\right), 70.34\left(-\mathrm{CH}_{2} \mathrm{CH}_{2} \mathrm{O}\right), 71.51\left(-\mathrm{OCH}_{2} \mathrm{CONH}\right), 73.8\left(-\mathrm{CHCO}_{2} \mathrm{H}\right)$, $163.01(-\mathrm{CONH}), 174.3\left(-\mathrm{CO}_{2} \mathrm{H}\right)$.

General procedure for the synthesis of Brij 78-NTA-Ni conjugate: Brij 78-NTA (1.22g, $8.5 \times 10^{-4} \mathrm{~mol}, 1$ equiv) was introduced to a round bottom flask equipped with a magnetic stir bar in DI water $(50 \mathrm{~mL})$, and the $\mathrm{pH}$ was adjusted to $\sim \mathrm{pH} 8$ with $1 \mathrm{~N} \mathrm{NaOH}(0.5 \mathrm{~mL})$. $\mathrm{NiCl}_{2} \cdot 6 \mathrm{H}_{2} \mathrm{O}\left(0.4,1.7 \times 10^{-3} \mathrm{~mol}, 2\right.$ equiv $)$ was added, and the solution was stirred at room temperature overnight. The nickel-chelated conjugate was purified using a Zeba ${ }^{\circledR}$ desalting column to remove the excess $\mathrm{NiCl}_{2}$. The percent chelation was quantified by ICP-MS analysis in reference to the amount of $\mathrm{Ni}$ in the solution prior to purification.

General procedure for the synthesis of Brij 700-NTA-Ni: Brij 700-NTA-Ni was synthesized following the same procedure outlined above for Brij 78-NTA-Ni.

\subsection{Formulation of Ni-NPs}

General procedure for the preparation of Ni-NPs using Brij 700-NTA-Ni: Nanoparticles were prepared from warm oil/water $(\mathrm{o} / \mathrm{w})$ microemulsion precursors following a previously reported procedure.[29] In the optimized formulation, Brij 78 (2.9 mg), TPGS (1.5 mg), Miglyol $812(2.5 \mathrm{mg})$, and Brij 700-NTA-Ni $(0.6 \mathrm{mg}, 8 \mathrm{wt} . \%)$ were weighed into a $7 \mathrm{~mL}$ glass vial and heated in a water bath to $65^{\circ} \mathrm{C}$ to melt and blend the excipients. A small amount of ethanol $(100 \mu \mathrm{L})$ was added to the melted excipients and the solution was swirled to help form a homogenous mixture. The ethanol was removed completely using a stream of 
nitrogen and the vial was transferred to a water bath at $65^{\circ} \mathrm{C}$. "One (1) $\mathrm{mL}$ of filtered and deionized (D.I.) water pre-heated at $65^{\circ} \mathrm{C}$ was added into the mixture of melted oil and surfactants, and the solution was stirred for $30 \mathrm{~min}$ at $65^{\circ} \mathrm{C}$ then cooled to room temperature.

General procedure for the preparation of Ni-NPs using Brij 78-NTA-Ni: Nanoparticles were prepared from warm o/w microemulsion precursors as described above with some modification. In the optimized formulation, Brij $78(0.7 \mathrm{mg})$, Brij 78-NTA-Ni (2.8 mg), TPGS $(1.5 \mathrm{mg})$, and Miglyol $812(2.5 \mathrm{mg})$ were weighed into a $7 \mathrm{~mL}$ glass vial and heated in a water bath to $65^{\circ} \mathrm{C}$ to melt and blend the excipients. A small amount of ethanol (100 $\mu \mathrm{L}$ ) was added to the melted excipients and the solution was swirled to help form a homogenous mixture. The ethanol was removed completely using a stream of nitrogen and the vial was transferred to a water bath at $65^{\circ} \mathrm{C}$. "One (1) $\mathrm{mL}$ of filtered and deionized (D.I.) water pre-heated at $65^{\circ} \mathrm{C}$ was added into the mixture of melted oil and surfactants, and the solution was stirred for $30 \mathrm{~min}$ at $65^{\circ} \mathrm{C}$ then cooled to room temperature.

\subsection{Optimization of histidine $\times 6$-tagged green fluorescent protein (his-tag GFP) binding to Ni-NPs-Briefly, $500 \mu \mathrm{L}$ of Ni-NPs was passed down a Sepharose} CL-4B size exclusion chromatography $(\mathrm{SEC})$ column $(15 \times 100 \mathrm{~mm})$ column using PBS, pH 7.4 as a mobile phase. Fractions $(1 \mathrm{~mL})$ were collected and those containing NPs (as determined by dynamic light scattering measurement of particle size) were combined and used for binding his $\times 6$-tagged GFP. Binding studies of his $\times 6$-tagged GFP to Ni-NPs prepared with Brij 700-NTA-Ni were carried out using optimal binding conditions at a ratio of $0.0045 \mathrm{w} / \mathrm{w}$ his $\times 6$-tagged GFP to Ni-NPs. The Ni-NPs were incubated with the corresponding amount of his $\times 6$-tagged GFP in PBS, pH 7.4 at $4^{\circ} \mathrm{C}$ overnight. Free his $\times 6$ tagged GFP was removed by a Sepharose CL-4B SEC column $(15 \times 70 \mathrm{~mm})$ with PBS, pH 7.4 as the mobile phase. Fractions 1-24 $(1 \mathrm{~mL})$ were collected and analyzed by fluorescence spectroscopy to determine the percent of his $\times 6$-tagged GFP bound to the Ni-NPs. The fluorescence was measured using a BioTek Synergy 2 Fluorescence Spectrometer (Winooski, VT) with excitation and emission wavelengths set at 494 and $518 \mathrm{~nm}$, respectively.

\subsection{Optimization of his $\times 6$-tagged heptameric $Z$ EGFR domain binding to Ni-NPs}

-The Ni-NPs prepared with Brij 78-NTA-Ni were purified as described above and incubated with FITC-labeled heptameric $\mathrm{Z}^{\mathrm{EGFR}}$ domain at 2.5, 3.5, 5.0, 10 and $15 \mu \mathrm{g}$ liagnd/ $1500 \mu \mathrm{g}$ Ni-NPs to determine the optimal binding conditions. Unbound targeting ligand was separated by SEC column using PBS, pH 7.4 as the mobile phase. Fractions 1-24 (1 mL) were collected and analyzed by fluorescence spectroscopy to determine the percent of his $\times 6$ tagged FITC-labeled heptameric $\mathrm{Z}^{\mathrm{EGFR}}$ domain bound to the Ni-NPs. The fluorescence was measured with excitation and emission wavelengths set at 494 and $516 \mathrm{~nm}$, respectively.

2.5. In vitro cell uptake studies-The EGFR-overexpressing A431 cell line was used to investigate the uptake of EGFR-targeted Ni-NPs. A431 cells (passage 3) were cultured under standard conditions $\left(37^{\circ} \mathrm{C}, 95 \%\right.$ relative humidity, $5 \% \mathrm{CO}_{2}$ in Dulbecco's Modified Eagle Medium, high glucose (DMEM) supplemented with $10 \%$ fetal bovine serum (FBS) and $1 \%$ penicillin/streptomycin). For cell uptake experiments, the confluent cells were trypsinized and centrifuged using a Beckman Coulter, Allegra ${ }^{\mathrm{TM}} \mathrm{X}-12 \mathrm{R}$ Centrifuge at 900 $\mathrm{rpm}$ for $5 \mathrm{~min}$. The resulting cell pellet was re-suspended in the required amount of complete medium (DMEM) to achieve a cell-plating density of 20,000 cells per $\mathrm{mL}$ of medium. The cells were plated into 24-well tissue culture flat bottom plates (Corning/Costar 3526 ) and allowed to incubate overnight to about $40-50 \%$ confluency. The following day, untargeted and EGFR-targeted Ni-NPs were diluted in complete medium to obtain a final assay concentration of 1,5 , and $15 \mu \mathrm{g} / \mathrm{mL}$. NPs $(300 \mu \mathrm{L})$ were then incubated with cells 
over a time course ranging from $15 \mathrm{~min}$ to $4 \mathrm{~h}\left(37^{\circ} \mathrm{C}, 5 \% \mathrm{CO}_{2}\right)$. After cell/NPs incubation, the cells were washed with $1 \times$ Dulbecco's Phosphate Buffered Saline solution (D-PBS) and detached by trypsinization $(300 \mu \mathrm{L} /$ well $)$. Cells were resuspended in a $1: 1$ solution of $0.4 \%$ trypan blue (TB) solution in $1 \times$ D-PBS containing $10 \%$ FBS $(500 \mu \mathrm{L} /$ well; total sample volume $800 \mu \mathrm{L}$ ) and transferred to a $5 \mathrm{ml}$ Falcon (352063) polypropylene round-bottom tube. This assay relies on the observation that the FITC-label of non-internalized particles acquires red fluorescence while losing its green fluorescence when incubated with the vital dye TB. Internalized particles on the other hand will fluoresce green.[30] Cells (10,000 per sample) were analyzed by flow cytometry (CyAn ADP, Dako), for green and red fluorescence.

2.6. In vivo studies-Female nude athymic (nu/nu) mice, 4 to 6 wk (Harlan Laboratories), were housed in a pathogen-free room. All experiments involving the mice were carried out with an approved protocol by the University of North Carolina Animal Care and Use Committee. The mice were injected s.c. in the right flank region with $2 \times 10^{6}$ A431 cells suspended in DMEM. Tumors were measured in two perpendicular dimensions, and tumor volume was calculated using the formula $V=\left(L \times W^{2}\right) / 2$, where $L$ and $W$ are the longest and shortest diameters, respectively. When the tumors reached volumes between $300-500 \mathrm{~mm}^{3}$, the mice were randomly divided into three groups, a naïve group, a group injected with untargeted Ni-NPs and a third group injected with EGFR-targeted Ni-NPs using his $\times 6$-tagged, Alexa750-labeled heptameric $Z^{\mathrm{EGFR}}$ domain. Mice were injected with $\mathrm{Ni}$-NPs in $200 \mu \mathrm{L}$ of isotonic saline solutions via intravenous (i.v.) injection.

2.6.1. Intracellular tumor cell analysis of delivered Ni by ICP-MS: To evaluate the efficacy of the heptameric $Z^{\text {EGFR }}$ domain in targeting Ni-NPs, Ni concentrations within cells extracted from tumor homogenates were quantified by ICP-MS analysis. The mice were euthanized and the tumors were harvested and transferred to a solution of phosphate buffered saline (PBS, $5 \mathrm{~mL}$ ) containing Fungizone (0.01\%) and Penstrep (0.01\%). The tumors were then transferred to a $50 \mathrm{~mL}$ Falcon tube containing $5 \mathrm{~mL}$ of complete DMEM, and homogenized using a Tissue Tearor ${ }^{\mathrm{TM}}$ (Biospec products, Inc.) homogenizer. To dissociate single cells from tumor fragments, $20 \mathrm{~mL}$ of tumor digestion enzyme mixture (Hyaluronidase, Type V; Collagenase, type IV and DNase, Type IV, Sigma Aldrich) was added to the medium containing the cell homogenate, and the solution was mixed thoroughly followed by incubation for $3 \mathrm{~h}$ at $37^{\circ} \mathrm{C}$ with periodical mixing every $10-15$ min. The cell homogenate solution was passed first, through a $70 \mu \mathrm{m}$ sterile mesh filter, and a second time through a $40 \mu \mathrm{m}$ sterile filter to ensure removal of any large undigested tumor fragments. The filtrate was centrifuged (Thermo IEC CL40R centrifuge) at $1100 \mathrm{rpm}$ for 5 min. The resulting cell pellet was re-suspended in $9 \mathrm{~mL}$ of $1 \times$ Osmotic Lysis Buffer for 30 sec with continuous mixing to remove any red blood cells (RBC) contaminant. The cell suspension was centrifuged at $1100 \mathrm{rpm}$ for $5 \mathrm{~min}$, and the resulting cell pellet was resuspended in lysis buffer for $15 \mathrm{~min}$ at room temperature. Finally, the cell suspension was centrifuged at $1100 \mathrm{rpm}$ for $5 \mathrm{~min}$, and the resulting cell pellet was rinsed twice with Hank's buffer salt solution (HBSS, $5 \mathrm{~mL})$. The cell pellet was re-suspended in HBSS $(0.5 \mathrm{~mL})$ and $2 \%$ nitric acid $(2.5 \mathrm{~mL})$ for ICP-MS analysis to quantify intracellular Ni accumulation within the tumor homogenate. $2 \%$ nitric acid was used for digestion and solubility purposes for ICP-MS analysis.

2.6.2. In vivo optical imaging: Fluorescence imaging studies were carried out 16 h post i.v. injection, using the IVIS ${ }^{\circledR}$ Spectrum (Caliper Life Sciences) with an epi-illumination (from the top) capability to illuminate in vivo fluorescent sources. Two weeks prior to i.v. injection, the mice were kept under alfalfa-free diet to minimize background fluorescence from the food. The heptameric $Z^{E G F R}$ domain was labeled with Alexa750 and conjugated to 
the Ni-NPs via noncovalent Ni- his $\times 6$-tag affinity binding. The mice were anesthetized using isoflurane and transferred to the IVIS instrument to collect full body images (Ex. 745 $\mathrm{nm}$ and Em. $800 \mathrm{~nm}$ ). The mice were given an overdose of ketamine and domitor to deeply anesthetize them prior to cardiac puncture to collect blood, and a cervical dislocation was then performed to euthanize the mice. The organs/tumors were harvested and transferred to 12-well plates and imaged using IVIS at $30 \mathrm{sec}$ scanning time. Tumors and organs were weighed and percent fluorescence was qualitatively evaluated based on the total fluorescence detected from all organs, tumors and blood.

\section{Statistical Analysis}

Statistical analysis was performed using one-way analysis of variances (ANOVA) followed by pair-wise comparisons using Tukey's multiple comparison test using GraphPad Prism Software $\left({ }^{\circledR} 1992-2007\right.$ GraphPad Prism Software, Inc). Results were considered significant at $95 \%$ confidence interval $(p<0.05)$.

\section{Results and Discussion}

\section{Synthesis}

Brij 700-NTA-Ni and Brij 78-NTA-Ni conjugates were prepared using the same synthetic strategy. For Brij 700-NTA-Ni, this was accomplished by first converting the terminal hydroxyl group of polyoxyl 100-stearyl ether (Brij 700) to a carboxylic acid group using the TEMPO-mediated oxidation.[31] The carboxylic acid derivative (2) of Brij 700 was subsequently reacted with excess $N$-hydroxysuccinimide (NHS) and 1-(3Dimethylaminopropyl)-3-ethylcarbodiimide hydrochloride (EDC). The resulting NHSactive ester of Brij 700-acid (3) was subsequently reacted with nitrilotriacetic acid (NTA) to give Brij 700-NTA conjugate. The chelation of nickel to Brij 700-NTA (4) was carried out using excess $\mathrm{NiCl}_{2} \cdot 6 \mathrm{H}_{2} \mathrm{O}$ to obtain the final conjugate (Scheme 1).[32] The excess $\mathrm{NiCl}_{2}$ was removed using a Zeba desalting column and the purified conjugate was analyzed by inductively coupled mass spectrometry (ICP-MS) analysis to quantify the amount of Ni chelated to the NTA head group of the Brij 700-NTA conjugate. Results from ICP-MS analysis showed that the ratio of Brij 700- NTA to Ni was close to 1:1 after purification with a Zeba desalting column indicating near quantitative yields (Table 1).

\section{Optimization of BTM-Ni NPs formulation using Brij 700-NTA-Ni}

The preparation of Niloaded BTM NPs (Ni-NPs) can be carried out in a number of ways, including (a) the use of the commercially available DOGS-NTA-Ni conjugate which can be incorporated into the lipid core of the BTM NPs, (b) the use of Brij 700-NTA-Ni synthesized from Brij 700 previously added as a pegylation agent for the original BTM NPs formulation, (c) the use of Brij 78-NTA-Ni synthesized from Brij 78, the main surfactant component in the BTM NP formulation. Previous studies in our lab showed that the use of DOGS-NTA-Ni to incorporate Ni in lipid-based NPs resulted in very little Ni incorporation $(<10 \%)$.[28] This is thought to be due to the hydrophobic nature of DOGS-NTA, which presumably incorporates within the NPs but limits accessibility of Ni to the surface of the NPs. This limitation can be addressed by conjugating the NTA-Ni head group to a molecule that would have both a hydrophilic chain to promote accessibility of Ni to the surface of the NPs, and a hydrophobic chain that would enhance incorporation of the conjugate within the lipid core of the NPs. To do this, a novel Brij 700-NTA-Ni conjugate was successfully synthesized using Brij 700. When Brij 700 was added as a PEGylating agent in the BTM NP formulation, the optimal amount was determined at 8\% w/w (Brij 700 to Miglyol 812).[33] Based on these findings, optimization of the new BTM-Ni NP formulation was carried out using various amounts of Brij 700-NTA-Ni conjugate ranging from 0.5-8\% w/w (Brij 700NTA-Ni to total NP) (Table 2). The Ni-NPs were characterized by measuring their particle 
size and zeta potential, and by ICP-MS analysis to quantify the percent $\mathrm{Ni}$ associated with each NP composition. The Ni-NPs had a mean size of $\sim 190 \mathrm{~nm}$ and exhibited an increasing negative charge with increasing $\mathrm{Ni}$ content ranging from $-12 \mathrm{mV}$ to $-22 \mathrm{mV}$ (Table 3).

\section{Incorporation efficiency of Brij 700-NTA-Ni in NPs based on Ni content}

The concentration of $\mathrm{Ni}$ in the various NP formulations was quantified by ICP-MS analysis. Prior to analysis, the Ni-NPs were purified by size exclusion chromatography (SEC) using a Sepharose CL-4B packed column to isolate NPs within the $200 \mathrm{~nm}$ range. Both unpurified and purified Ni-NPs were transferred to individual $15 \mathrm{~mL}$ Falcon tubes and diluted with $2 \%$ nitric acid $(10 \mathrm{~mL})$ for analysis. The percent $\mathrm{Ni}$ incorporation in the purified Ni-NPs was calculated in reference to the original Ni concentrations of the unpurified Ni-NPs. ICP-MS analysis showed a significant increase in Ni incorporation within the NPs (32-48\%, Table 4) compared to much lower incorporation efficiency (6-7\%) previously obtained with DOGSNTA-Ni.[34] Results also indicated that increasing Brij 700-NTA-Ni content beyond 2\% w/ $\mathrm{w}$ did not seem to further increase the incorporation efficiency of Ni within the NPs. This is likely due to an equilibrium factor between Brij 78 and Brij 700-NTA-Ni since the original amount of Brij 78 was reduced accordingly to compensate for the addition of Brij 700-NTA$\mathrm{Ni}$ and keep the total amount of surfactants constant in the NP formulation (Table 2).

Consequently, beyond a certain percent of Brij 700-NTA-Ni, a saturation point is reached, which makes incorporation within the NPs more difficult, resulting in a plateau at $\sim 50 \% \mathrm{Ni}$ incorporation (Table 4). However, the main goal of the present work was to design a system with a high $\mathrm{Ni}$ content but also with an incorporation efficiency that was close to quantitative in order to avoid extra purification steps to remove free NTA-Ni conjugate.

\section{Binding efficiency of his $\times 6$-tagged GFP to the Ni-NPs}

Based on the promising Ni incorporation results obtained with Brij 700-NTA-Ni, further work to evaluate binding efficiency of the Ni-NPs to his $\times 6$-tagged proteins was carried out using his $\times 6$-tagged GFP as a model protein. The Ni-NPs were incubated with his $\times 6$-tagged GFP at a previously optimized ratio (data not shown) of $0.0045 \mathrm{w} / \mathrm{w}$ his-GFP to NPs at $4^{\circ} \mathrm{C}$ overnight. SEC was used to separate unbound his $\times 6$-tagged GFP, and fractions $(1 \mathrm{~mL}) 1-24$ were collected and analyzed by fluorescence spectroscopy to determine the amount of fluorescence associated with the NPs fractions (4-7). The binding efficiency of his $\times 6$-tagged GFP to the Ni-NPs was $\sim 55 \%$ based on the percent fluorescence associated with the NPs fractions ( $2.46 \mu \mathrm{g} \mathrm{GFP} / \mathrm{mg}$ NPs). Surprisingly, these values were comparable to the binding efficiency of his-GFP to Ni-NPs prepared with DOGS-NTA-Ni $(\sim 48 \%, 2.19 \mu \mathrm{g}$ GFP/mg NPs) (Table 5). Given the 8-fold increase in Ni incorporation using Brij 700-NTA$\mathrm{Ni}$, these results suggested that the binding efficiency of his $\times 6$-tagged GFP to Ni-NPs was not proportional to the amount of Ni within the NPs alone. It was hypothesized that, the low binding efficiency of his $\times 6$-tagged GFP to the Ni- NPs was due to two reasons: 1) high chain dynamics and mobility in water of the long PEG chain (PEG MW $=4 \mathrm{kDa}$, Brij 700NTA-Ni) induced protein repulsion, $[35,36]$ therefore hindering his-GFP binding to the NiNPs, 2) An equilibrium phenomenon, which favors Brij 700-NTA-Ni to be in the aqueous environment surrounding the NPs rather than its incorporation within the lypophilic core of the NPs. To test these hypotheses, an intermediate conjugate between the fully lypophilic DOGS-NTA-Ni and Brij 700-NTA-Ni with the long PEG chain was synthesized. This was accomplished using polyoxyl 20-stearyl ether (Brij 78) (MW = $1152 \mathrm{Da}$ ), the main surfactant in the BTM NP formulation, which differs from Brij 700 only in the length of the PEG chain $(\mathrm{Mw}=4400 \mathrm{Da}$ for Brij 700 versus $\mathrm{Mw}=880 \mathrm{Da}$ for Brij 78).

\section{Optimization of Ni-NP formulation for binding to his $\times 6$-tagged GFP using Brij 78-NTA-Ni}

Synthesis of Brij 78-NTA-Ni was carried out following the same synthetic steps used to make Brij 700-NTA-Ni conjugate (Scheme 1). In this new formulation, 50 wt.\% of Brij 78 
in the original BTM NP formulation[37] was substituted with Brij 78-NTA-Ni. The percent incorporation of Ni using Brij 78-NTA-Ni was significantly higher, where $89 \%$ of the original Ni amount was associated with the NPs fraction as determined by ICP-MS analysis (Table 5). The structural similarity of Brij 78-NTA-Ni and Brij 78, the main surfactant in the NPs formulation, allowed incorporation of greater amounts (up to $80 \mathrm{wt} . \%$ ) of Brij 78-NTA$\mathrm{Ni}$ in the NPs formulation resulting in enhanced $\mathrm{Ni}$ incorporation. This was not the case with Brij 700-NTA-Ni, where the optimal amount that could be added to the NPs formulation was $8 \mathrm{wt} . \%$. These results were extremely promising in that being able to achieve nearly quantitative Ni incorporation with Brij 78-NTA-Ni allowed for the development of a formulation that can readily be used for in vitro and in vivo studies. Moreover, when increasing the amount of Brij 78-NTA-Ni to 80\% w/w (Brij 78-NTA-Ni to Brij 78), there was no significant enhancement in the percent Ni incorporation (90\%) within the NPs. This suggested that increasing the amount of Brij 78-NTA-Ni beyond 50\% w/w did not further enhance percent $\mathrm{Ni}$ incorporation within the NPs.

Binding studies of his $\times 6$-tagged GFP to this new Ni-NPs formulation were carried out using the aforementioned optimal binding conditions ( $0.0045 \mathrm{w} / \mathrm{w}$ his $\times 6$-tagged GFP to Ni-NPs). Fluorescence analysis of SEC fractions showed a significant enhancement in binding efficiency $(\sim 85 \%, 3.83 \mu \mathrm{g}$ GFP/mg NPs) compared to previous results obtained with Brij 700-NTA-Ni based NPs ( $\sim 55 \%, \sim 2.46 \mu \mathrm{g}$ GFP/mg NPs) (Table 5). These results support our hypothesis that by shortening the length of the PEG segment on the NTA-Ni conjugate, enhanced Ni incorporation and binding efficiencies to a his $\times 6$-tagged protein were observed. Based on these results, optimization studies for binding of a novel his $\times 6$-tagged heptameric $Z^{\text {EGFR }}$ domain to the new Ni-NPs to target them to EGFR-overexpressing cancer cells were carried out.

\section{Optimization of FITC-labeled his $\times 6$-tagged heptameric ZEGFR domain binding to the Ni-NPs}

One of the main limitations of coupling proteins to carriers using a noncovalent his-tag-Ni interaction is the potential disruption of the his-Ni-NTA association in vivo. Szoka et al. showed that while increasing the retention of his $\times 6$-tagged proteins to multivalent NTA headgroups in vitro, this association was not robust enough in vivo.[38] In the present work, we investigated the potential improvement of the his-tag-Ni-NTA association in vivo using a multi-his $\times 6$-tagged protein (heptameric $Z^{\text {EGFR }}$ domain) to bind to a NP system that exhibits high $\mathrm{Ni}$ content and improved $\mathrm{Ni}$ accessibility to the his $\times 6$-tagged protein.

The high affinity $\left(K_{\mathrm{d}}=29 \mathrm{pM}\right)$ heptameric $Z^{\text {EGFR }}$ domain was prepared by fusing a heptamerization domain with an EGFR-binding $Z$ domain. This process allowed for the formation of a highly stable heptameric structure, without formation of other multimeric intermediates. The targeting ligand was terminated with a his $\times 6$-tag to allow for site-specific attachment to Ni-NPs via Ni-his-tag affinity binding.

Binding studies were accomplished using FITC-labeled heptameric $Z^{\text {EGFR }}$ domain (FITChis $\times 6$-tagged heptamer) at various FITC-his-heptamer to Ni-NPs w/w ratios to determine the optimal conditions. SEC followed by fluorescence analysis showed that a binding ratio of $0.002 \mathrm{w} / \mathrm{w}$ (his $\times 6$-tagged-heptamer to Ni-NPs) or lower yielded binding efficiencies $>90 \%$ (Fig. 1, Table 6). These optimization studies were particularly important in minimizing purification steps required to separate unbound protein from NP-bound protein prior to in vitro and in vivo studies. Based on these results, in vitro and in vivo studies were completed with the optimal binding conditions of $0.002 \mathrm{w} / \mathrm{w}$ his $\times 6$-tagged-heptamer to Ni-NPs ratio. 


\section{Facilitated in vitro cell uptake of EGFR-targeted Ni-NPs in EGFR+ cancer cells}

In vitro cell uptake studies were carried out to determine the percent internalization of the targeted Ni-NPs in EGFR overexpressing epidermoid carcinoma cells, A431. Dose and time dependency of cell uptake was investigated at Ni-NPs concentrations of 1,5 and $15 \mu \mathrm{g} / \mathrm{mL}$ and three time points ( $15 \mathrm{~min}, 1 \mathrm{~h}$ and $4 \mathrm{~h})$. Cell uptake was quantified by flow cytometry analysis using a trypan blue (TB) assay that is based on the observation that the vital dye $\mathrm{TB}$, while quenching the FITC fluorescence of non-internalized particles causing them to fluoresce red, it induces internalized particles to fluoresce green.[30] Flow cytometry data showed up to $90 \%$ internalization of the EGFR-targeted Ni-NPs in the A431 cells with the highest concentration of NPs (15 $\mu \mathrm{g} / \mathrm{mL})$ and longest incubation time (4 h) (Fig. 2A). ICPMS analysis, used to quantify cell-internalized $\mathrm{Ni}$, were in good agreement with flow cytometry results showing a dose dependent increase in Ni internalization in A431 cells (Fig. 2B).

Cell uptake competition studies were also carried out by first incubating the cells with free unlabeled heptameric $\mathrm{Z}^{\mathrm{EGFR}}$ domain for $30 \mathrm{~min}$ at various concentrations ranging from $0.035 \mathrm{ng} / \mathrm{mL}$ to $3.5 \mu \mathrm{g} / \mathrm{mL}$ and then adding EGFR-targeted Ni-NPs $(15 \mu \mathrm{g} / \mathrm{mL})$ and incubating for an additional $4 \mathrm{~h}$. The percent internalization of the targeted Ni-NPs in the A431 cells was competed off with free heptameric $Z^{\text {EGFR }}$ domain concentrations of $8.75 \mathrm{ng} /$ $\mathrm{mL}$ or higher (Fig. 3A). It is also noteworthy that the concentration of heptameric $Z^{\text {EGFR }}$ domain present in the targeted Ni-NPs when incubated at $15 \mu \mathrm{g} / \mathrm{mL}$ was $35 \mathrm{ng} / \mathrm{mL}$. Interestingly, the competition studies showed that the most significant decrease in cell internalization of the targeted Ni-NPs occurred when the concentration of the free heptameric $Z^{\text {EGFR }}$ domain exceeded $35 \mathrm{ng} / \mathrm{mL}$ (Fig. 3A). As shown in Fig. 3B, it was also demonstrated that increasing the heptameric $Z^{\text {EGFR }}$ domain concentration on the surface of the Ni-NPs, significantly enhanced the uptake of the NPs in EGFR-overexpressing A431 cells (as measured by cell internalized Ni using ICP-MS analysis).

All together, these in vitro results were very encouraging in that they demonstrated superior cell uptake could be achieved in EGFR overexpressing cells with these Ni-NPs when targeted with the novel heptameric $\mathrm{Z}^{\mathrm{EGFR}}$ domain.

\section{Facilitated in vivo accumulation of EGFR-targeted Ni-NPs in EGFR+ cancer cells}

Based on the results obtained from the in vitro studies, a preliminary in vivo study was carried out to test the efficacy of the novel heptameric $Z^{\mathrm{EGFR}}$ domain in targeting the new Ni-NPs. The in vivo study was performed in female nude athymic (nu/nu) mice bearing A431 tumors to determine the biodistribution and intracellular delivery of the EGFRtargeted Ni-NPs. IVIS fluorescence imaging (to detect Alexa750-labeled heptameric Z ${ }^{\text {EGFR }}$ domain) and ICP-MS (to detect $\mathrm{Ni}$ ) were both utilized to monitor untargeted and targeted Ni-NPs. Whole-body fluorescence imaging demonstrated visible tumor accumulation of the targeted Ni-NPs with no accumulation in the heart, lungs, stomach, intestines, or spleen (Fig. 4). Using the same female nude athymic (nu/nu) mice, qualitative biodistribution data were collected by harvesting the organs and tissues at $16 \mathrm{~h}$ post injection of untargeted and targeted Ni-NPs via tail vein. The organs and tissues harvested from each mouse included blood (via heart puncture), tumors, heart, lung, liver, kidneys, intestines, spleen and bladder. Semiquantitative information was obtained by defining regions of interest (ROIs) on the images and determining the number of counts in that volume. Fig. 5A depicts the relative fluorescence intensity measured, normalized to the point of maximum intensity. These results were in agreement with the whole-body images showing modest accumulation in the liver and a stronger signal in the kidneys, presumably due to heptameric $\mathrm{Z}^{\mathrm{EGFR}}$ domain elimination. The fluorescence intensity for EGFR-targeted Ni-NPs in the tumors was $19 \%$ of the total detected fluorescence intensity (FI). An additional 28\% FI was detected in the liver 
and $42 \%$ FI was detected in the kidneys (Table 7). In parallel to the fluorescence imaging studies, Ni accumulation in the tumor cells was quantified by ICP-MS analysis. Tumors were harvested $16 \mathrm{~h}$ post i.v. injection, and tumor cells were extracted from the tumor homogenates and analyzed for intracellular $\mathrm{Ni}$ accumulation. A significant enhancement of intracellular Ni accumulation was detected for the targeted Ni-NPs (Fig. 5B). The percent intracellular $\mathrm{Ni}$ accumulation was $8 \%$ of the total injected dose (ID) of $\mathrm{Ni}$, almost a two-fold increase from untargeted Ni-NPs (5\%). Collectively, these new preliminary data were very promising and support the development of the novel heptameric $\mathrm{Z}^{\mathrm{EGFR}}$ domain to target EGFR overexpressing cancer cells.

\section{Conclusions}

The synthesis of two new NTA-Ni conjugates was successfully accomplished with both Brij 700 and Brij 78. Using these new conjugates, Ni-NPs with high Ni incorporation ( 50\% and $\sim 90 \%$ respectively) and facilitated Ni access to the surface of the NPs were prepared. Combined, these two advantages resulted in enhanced binding efficiencies of his $\times 6$-tagged GFP to the Ni-NPs. Interestingly, higher binding efficiencies to his $\times 6$-tagged GFP were observed for Ni-NPs prepared with Brij 78-NTA-Ni conjugate (85\% vs. 55\%). These results suggested that conjugating the NTA-Ni group to a shorter PEG chain (Brij 78 vs. Brij 700) promoted greater protein binding via his-tag-Ni affinity interaction. The new Ni-NPs $(80 \%$ w/w Brij 78-NTA-Ni) were decorated with a novel his $\times 6$-tagged heptameric $Z^{\text {EGFR }}$ domain with up to $95 \%$ binding efficiency at optimal conditions $\left(0.002 \mathrm{w} / \mathrm{w} \mathrm{Z}^{\mathrm{EGFR}}\right.$ domain to NiNPs). In vitro cell uptake studies showed up to $90 \%$ internalization of the EGFR-targeted Ni-NPs into the EGFR overexpressing A431 cells, as compared to significantly lower uptake $(<10 \%)$ of the untargeted Ni-NPs. The targeting efficiency of the novel heptameric $Z^{\text {EGFR }}$ domain was also demonstrated in vivo with almost a two-fold increase in intracellular $\mathrm{Ni}$ accumulation in tumor homogenates.

To our knowledge, this is the first report on the use of a novel heptameric $Z^{E G F R}$ domain to successfully target EGFR overexpressing cancer cells and the data support the development of the novel heptameric $Z^{\text {EGFR }}$ domain to target EGFR overexpressing cancer cells. Future studies will focus on translating the use of the novel heptameric $Z^{\mathrm{EGFR}}$ domain to target drug-loaded NPs to EGFR overexpressing breast cancer cells (MDA-MB-468) and EGFR overexpressing non-small cell lung cancer cells (A549).

\section{Acknowledgments}

The project described was supported by Award Number U54CA151652 from the National Cancer Institute to RJM, $\mathrm{JD}$, and RL. The content is solely the responsibility of the authors and does not necessarily represent the official views of the National Cancer Institute or the National Institutes of Health. The authors would like to thank Charlene Santos and the Animal Studies Core in the Lineberger Comprehensive Cancer Center for their help with the in vivo studies.

\section{References}

1. Gialeli C, Kletsas D, Mavroudis D, Kalofonos HP, Tzanakakis GN, Karamanos NK. Targeting epidermal growth factor receptor in solid tumors: critical evaluation of the biological importance of therapeutic monoclonal antibodies. Curr Med Chem. 2009; 16:3797-3804. [PubMed: 19747140]

2. Vermeer PD, Einwalter LA, Moninger TO, Rokhlina T, Kern JA, Zabner J, Welsh MJ. Segregation of receptor and ligand regulates activation of epithelial growth factor receptor. Nature. 2003; 422:322-326. [PubMed: 12646923]

3. Mendelsohn J, Baselga J. Status of epidermal growth factor receptor antagonists in the biology and treatment of cancer. J Clin Oncol. 2003; 21:2787-2799. [PubMed: 12860957] 
4. Nicholson RI, Gee JMW, Harper ME. EGFR and cancer prognosis. Eur J Cancer. 2001; 37:S9-S15. [PubMed: 11597399]

5. Real FX, Rettig WJ, Chesa PG, Melamed MR, Old LJ, Mendelsohn J. Expression of Epidermal Growth-Factor Receptor in Human Cultured-Cells and Tissues - Relationship to Cell Lineage and Stage of Differentiation. Cancer Res. 1986; 46:4726-4731. [PubMed: 3015394]

6. Yip WL, Weyergang A, Berg K, Tonnesen HH, Selbo PK. Targeted delivery and enhanced cytotoxicity of cetuximab-saporin by photochemical internalization in EGFR-positive cancer cells. Mol Pharm. 2007; 4:241-251. [PubMed: 17263556]

7. Yang XD, Jia XC, Corvalan JRF, Wang P, Davis CG, Jakobovits A. Eradication of established tumors by a fully human monoclonal antibody to the epidermal growth factor receptor without concomitant chemotherapy. Cancer Res. 1999; 59:1236-1243. [PubMed: 10096554]

8. Jones H, Goddard L, Gee J, Gee JM, Miscox S, Rubini M, Barrow D, Knowlden JM, Williams S, Wakeling AE, Nicholson RI. Endocr-Relat Cancer. 2004; 11:793-814. [PubMed: 15613453]

9. Cohen MH, Johnson JR, Chen YF, Sridhara R, Pazdur R. FDA drug approval summary: Erlotinib (Tarceva (R)) tablets. Oncologist. 2005; 10:461-466. [PubMed: 16079312]

10. Burris HA. Dual kinase inhibition in the treatment of breast cancer: Initial experience with the EGFR/ErbB-2 inhibitor lapatinib. Oncologist. 2004; 9:10-15. [PubMed: 15163842]

11. Jaramillo ML, Leon Z, Grothe S, Paul-Roc B, Abulrob A, McCourt MO. Effect of the anti-receptor ligand-blocking 225 monoclonal antibody on EGF receptor endocytosis and sorting. Exp Cell Res. 2006; 312:2778-2790. [PubMed: 16806168]

12. Kim IY, Kang YS, Lee DS, Park HJ, Choi EK, Oh YK, Son HJ, Kim JS. Antitumor activity of EGFR targeted $\mathrm{pH}$-sensitive immunoliposomes encapsulating gemcitabine in A549 xenograft nude mice. J Control Release. 2009; 140:55-60. [PubMed: 19616596]

13. Lukyanov AN, Elbayoumi TA, Chakilam AR, Torchilin VP. Tumor-targeted liposomes: doxorubicin-loaded long-circulating liposomes modified with anti-cancer antibody. J Control Release. 2004; 100:135-144. [PubMed: 15491817]

14. Friedman M, Orlova A, Johansson E, Eriksson TL, Hoiden-Guthenberg I, Tolmachev V, Nilsson FY, Stahl S. Directed evolution to low nanomolar affinity of a tumor-targeting epidermal growth factor receptor-binding affibody molecule. J Mol Biol. 2008; 376:1388-1402. [PubMed: 18207161]

15. Tolmachev V, Orlova A, Nilsson FY, Feldwisch J, Wennborg A, Abrahmsen L. Affibody molecules: potential for in vivo imaging of molecular targets for cancer therapy. Expert Opin Biol Th. 2007; 7:555-568.

16. Nygren PA. Alternative binding proteins: Affibody binding proteins developed from a small threehelix bundle scaffold. Febs J. 2008; 275:2668-2676. [PubMed: 18435759]

17. Nord K, Gunneriusson E, Ringdahl J, Stahl S, Uhlen M, Nygren PA. Binding proteins selected from combinatorial libraries of an alpha-helical bacterial receptor domain. Nat Biotechnol. 1997; 15:772-777. [PubMed: 9255793]

18. Steffen AC, Orlova A, Wikman M, Nilsson FY, Stahl S, Adams GP, Tolmachev V, Carlsson J. Affibody-mediated tumour targeting of HER-2 expressing xenografts in mice. Eur J Nucl Med Mol I. 2006; 33:631-638.

19. Wikman M, Steffen AC, Gunneriusson E, Tolmachev V, Adams GP, Carlsson J, Stahl S. Selection and characterization of HER2/neu-binding affibody ligands. Protein Eng Des Sel. 2004; 17:455462. [PubMed: 15208403]

20. Lee SB, Hassan M, Fisher R, Chertov O, Chernomordik V, Kramer-Marek G, Gandjbakhche A, Capala J. Affibody molecules for in vivo characterization of HER2-positive tumors by nearinfrared imaging. Clin Cancer Res. 2008; 14:3840-3849. [PubMed: 18559604]

21. Orlova A, Magnusson M, Eriksson TLJ, Nilsson M, Larsson B, Hoiden-Guthenherg I, Widstrom C, Carlsson J, Tolmachev V, Stahl S, Nilsson FY. Tumor Imaging using a picomolar affinity HER2 binding affibody molecule. Cancer Res. 2006; 66:4339-4348. [PubMed: 16618759]

22. Hoppmann S, Miao Z, Liu SL, Liu HG, Ren G, Bao AD, Cheng Z. Radio labeled AffibodyAlbumin Bioconjugates for HER2-Positive Cancer Targeting. Bioconjugate Chem. 2011; 22:413421. 
23. Smith B, Lyakhov I, Loomis K, Needle D, Baxa U, Yavlovich A, Capala J, Blumenthal R, Puri A. Hyperthermia-triggered intracellular delivery of anticancer agent to HER2(+) cells by HER2specific affibody (ZHER2-GS-Cys)-conjugated thermosensitive liposomes (HER2(+) affisomes). J Control Release. 2011; 153:187-194. [PubMed: 21501640]

24. Masek J, Bartheldyova E, Turanek-Knotigova P, Skrabalova M, Korvasova Z, Plockova J, Koudelka S, Skodova P, Kulich P, Krupka M, Zachova K, Czernekova L, Horynova M, Kratochvilova I, Miller AD, Zyka D, Michalek J, Vrbkova J, Sebela M, Ledvina M, Raska M, Turanek J. Metallochelating liposomes with associated lipophilised norAbuMDP as biocompatible platform for construction of vaccines with recombinant His-tagged antigens: Preparation, structural study and immune response towards rHsp90. J Control Release. 2011; 151:193-201. [PubMed: 21256901]

25. Szoka FC, Huang ZH, Hwang P, Watson DS, Cao LM. Tris-Nitrilotriacetic Acids of Subnanomolar Affinity Toward Hexahistidine Tagged Molecules. Bioconjugate Chem. 2009; 20:1667-1672.

26. Szoka FC, Huang ZH, Park JI, Watson DS, Hwang P. Facile synthesis of multivalent nitrilotriacetic acid (NTA) and NTA conjugates for analytical and drug delivery applications. Bioconjugate Chem. 2006; 17:1592-1600.

27. van Broekhoven CL, Altin JG. The novel chelator lipid 3(nitrilotriacetic acid)-ditetradecylamine (NTA(3)-DTDA) promotes stable binding of His-tagged proteins to liposomal membranes: Potent anti-tumor responses induced by simultaneously targeting antigen, cytokine and costimulatory signals to T cells. Bba-Biomembranes. 2005; 1716:104-116. [PubMed: 16225839]

28. Patel JD, O'Carra R, Jones J, Woodward JG, Mumper RJ. Preparation and characterization of nickel nanoparticles for binding to his-tag proteins and antigens. Pharm Res. 2007; 24:343-352. [PubMed: 17180725]

29. Oyewumi MO, Mumper RJ. Gadolinium-loaded nanoparticles engineered from microemulsion templates. Drug Dev Ind Pharm. 2002; 28:317-328. [PubMed: 12026224]

30. Fattorossi A, Nisini R, Pizzolo JG, Damelio R. New, Simple Flow-Cytometry Technique to Discriminate between Internalized and Membrane-Bound Particles in Phagocytosis. Cytometry. 1989; 10:320-325. [PubMed: 2653740]

31. Masson C, Scherman D, Bessodes M. 2,2,6,6-tetramethyl-1-piperidinyloxyl/[bis(acetoxy)iodo]benzene-mediated oxidation: A versatile and convenient route to poly(ethylene glycol) aldehyde or carboxylic acid derivatives. Journal of Polymer Science Part a-Polymer Chemistry. 2001; 39:4022-4024.

32. Kim SH, Jeyakumar M, Katzenellenbogen JA. Dual-mode fluorophore-doped nickel nitrilotriacetic acid-modified silica nanoparticles combine histidine-tagged protein purification with site-specific fluorophore labeling. J Am Chem Soc. 2007; 129:13254-13264. [PubMed: 17910454]

33. Dong XW, Mattingly CA, Tseng MT, Cho MJ, Liu Y, Adams VR, Mumper RJ. Doxorubicin and Paclitaxel-Loaded Lipid-Based Nanoparticles Overcome Multidrug Resistance by Inhibiting PGlycoprotein and Depleting ATP. Cancer Res. 2009; 69:3918-3926. [PubMed: 19383919]

34. Patel JD, O'Carra R, Jones J, Woodward JG, Mumper RJ. Preparation and characterization of nickel nanoparticles for binding to his-tag proteins and antigens. Pharm Res. 2007; 24:343-352. [PubMed: 17180725]

35. Benhabbour SR, Liu L, Sheardown H, Adronov A. Protein resistance of surfaces prepared by chemisorption of monothiolated poly(ethylene glycol) to gold and dendronization with aliphatic polyester dendrons: Effect of hydrophilic dendrons. Macromolecules. 2008; 41:2567-2576.

36. Benhabbour SR, Sheardown H, Adronov A. Protein resistance of PEG-functionalized dendronized surfaces: Effect of PEG molecular weight and dendron generation. Macromolecules. 2008; 41:4817-4823.

37. Dong XW, Mattingly CA, Tseng M, Cho M, Adams VR, Mumper RJ. Development of new lipidbased paclitaxel nanoparticles using sequential simplex optimization. Eur J Pharm Biopharm. 2009; 72:9-17. [PubMed: 19111929]

38. Szoka FC, Platt V, Huang ZH, Cao LM, Tiffany M, Riviere K. Influence of Multivalent Nitrilotriacetic Acid Lipid-Ligand Affinity on the Circulation Half-Life in Mice of a LiposomeAttached His(6)-Protein. Bioconjugate Chem. 2010; 21:892-902. 


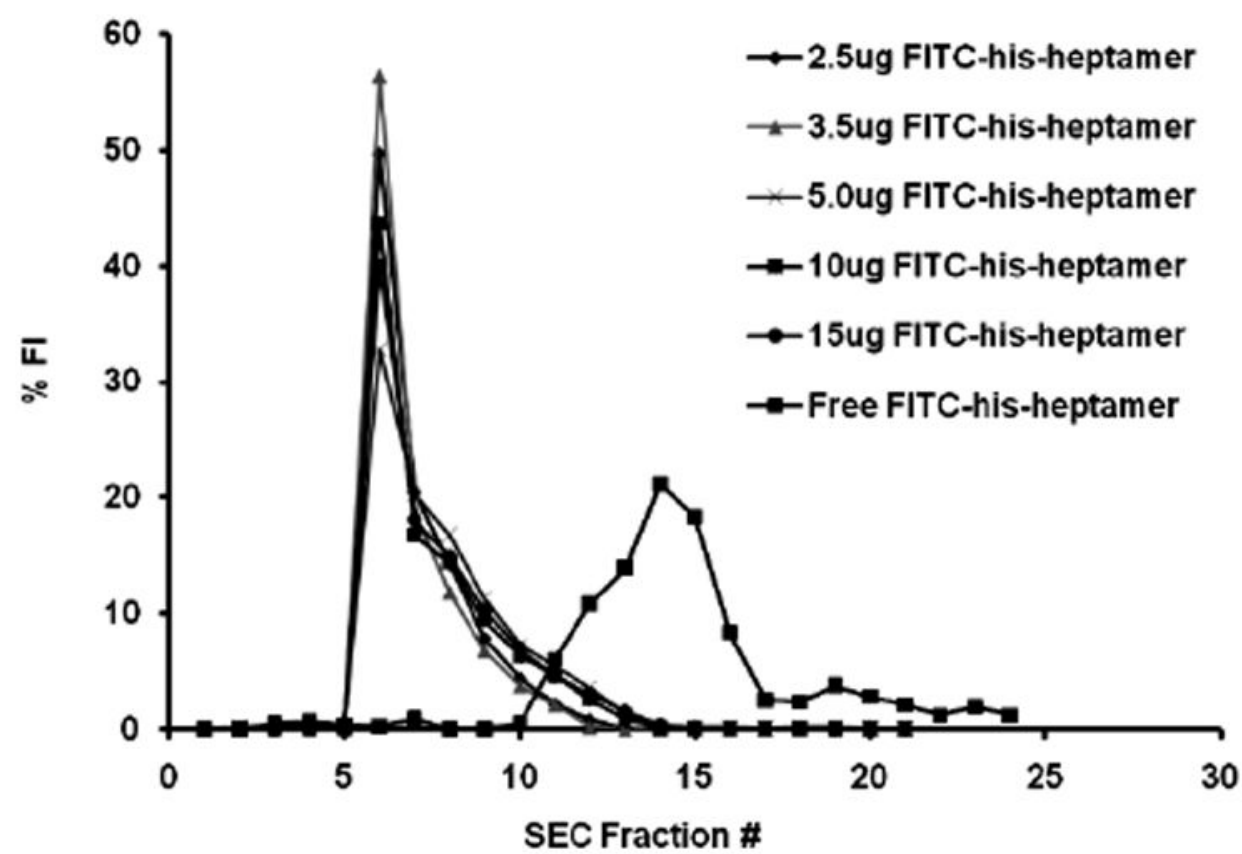

Fig. 1.

SEC separation profiles using Sepharose CL-4B column. Ni-NPs eluted in fractions 5-8 as determined by particle size intensity. Later fractions (9-15) contain micelles and unbound heptamer. The binding efficiency of FITC-his $\times 6$-tagged-heptamer was determined by separating NP-bound heptamer from free heptamer, which eluted in fractions 10-17 as determined by fluorescence intensity measurements. Percent binding of FITC-his-heptamer was determined by the percent fluorescence intensity associated with the Ni-NPs fraction. 
A

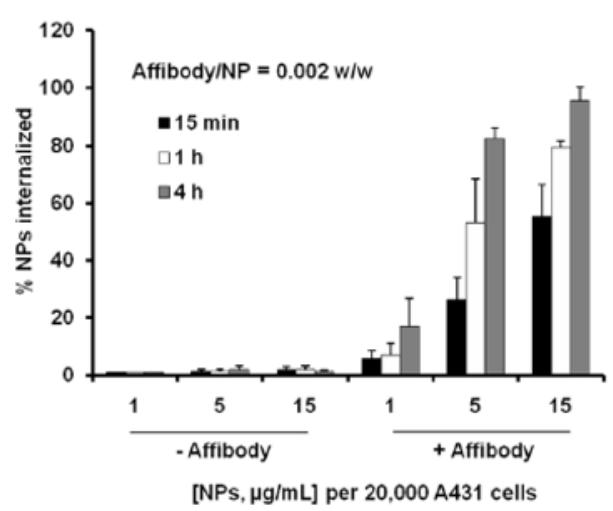

B

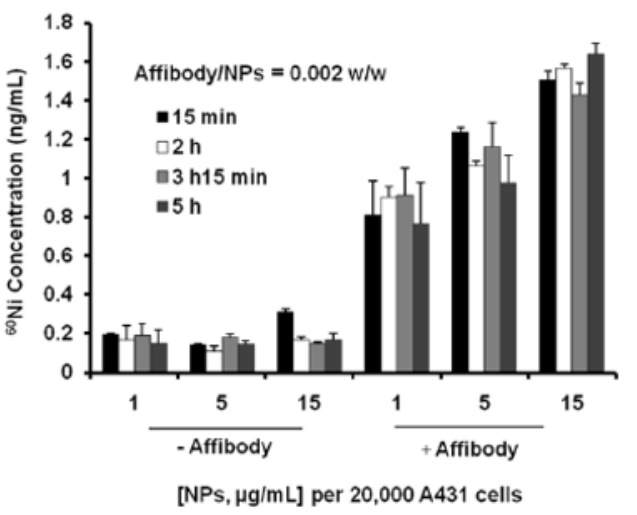

Fig. 2.

Cell uptake of untargeted and EGFR-targeted Ni-NPs. \% internalization of NPs as a function of dosage and incubation time. A) Flow cytometry analysis, B) ICP-MS analysis. Data in each group represents mean $\pm \mathrm{SD}(N=3, n=3)$. 
A

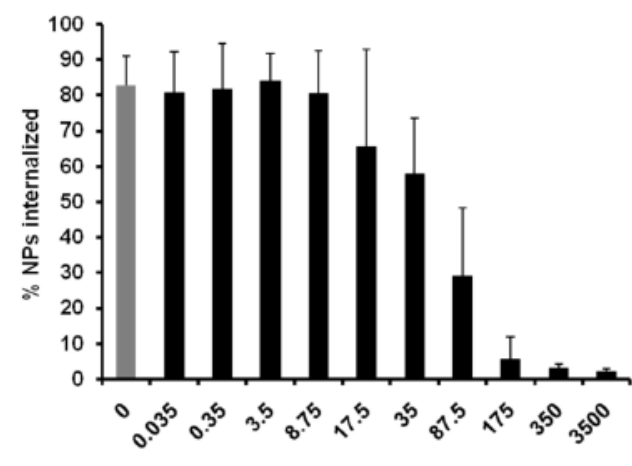

[Affibody, $\mathrm{ng} / \mathrm{mL}$ ] added $30 \mathrm{~min}$ prior to NPS
B

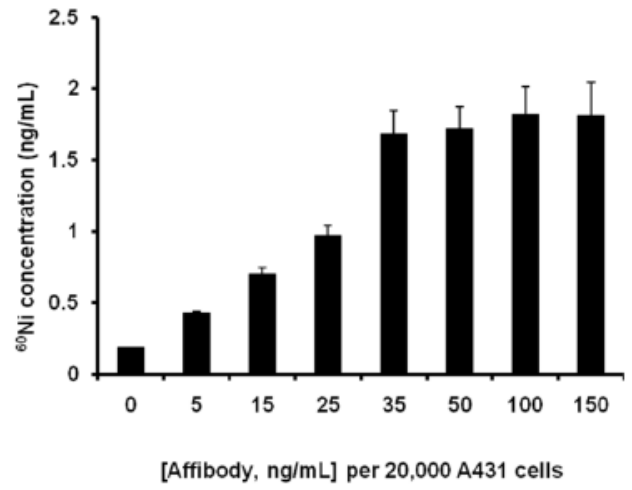

Fig. 3.

A) Cell uptake competition studies carried out with targeted Ni-NPs at $15 \mu \mathrm{g} / 20,000$ cells (with an equivalent amount of $35 \mathrm{ng} / 20,000$ cells of heptameric $\mathrm{Z}^{\mathrm{EGFR}}$ domain). Incubation time with the NPs was set to $4 \mathrm{~h}$, B) Effect of heptameric $Z^{\text {EGFR }}$ domain concentration on the uptake of NPs (as measured by internalized Ni concentration). Data in each group represents mean $\pm \mathrm{SD}(N=3, n=3)$. 

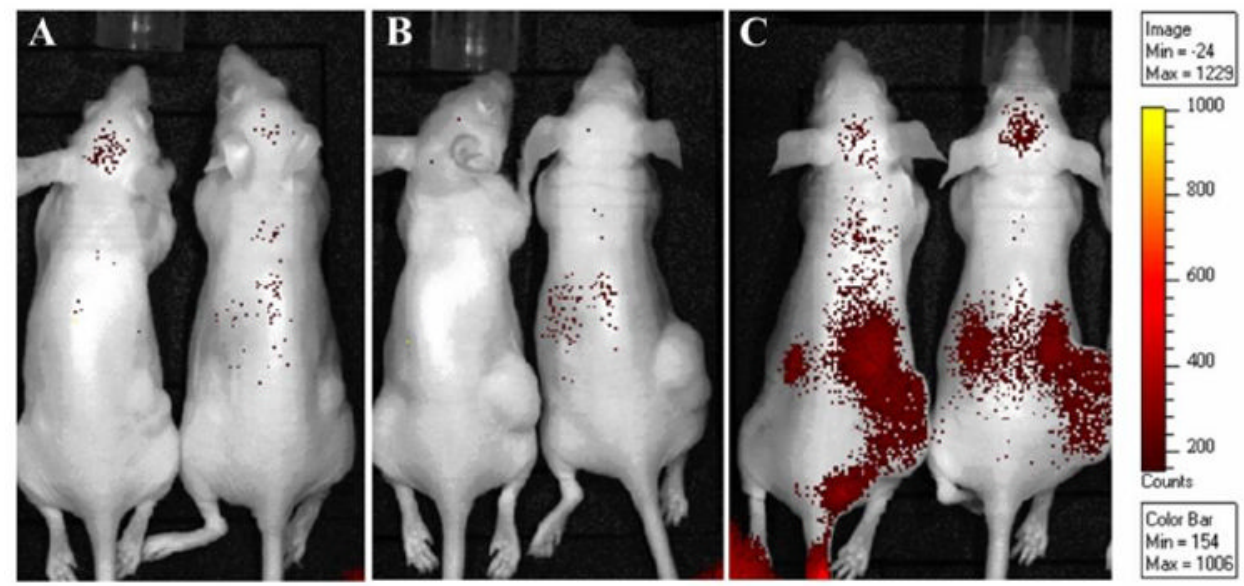

Fig. 4.

Biodistribution of heptameric EGFR-binding $Z^{\text {EGFR }}$ domain-targeted NPs $16 \mathrm{~h}$ after intravenous injection to A431-tumor bearing nude mice. Alexa750-labeled heptameric $\mathrm{Z}^{\mathrm{EGFR}}$ domain was used to evaluate biodistribution by optical imaging. Mice ( $\mathrm{n}=4$ /group) were injected with Ni-NPs with Alexa750-heptameric $Z^{\mathrm{EGFR}}$ domain and Ni doses of $5.8 \mu \mathrm{g}$ and $178 \mathrm{ng}$, respectively. IVIS fluorescence images of (A) Naïve, (B) Untargeted Ni-NPs, (C) Targeted Ni-NPs. 
A

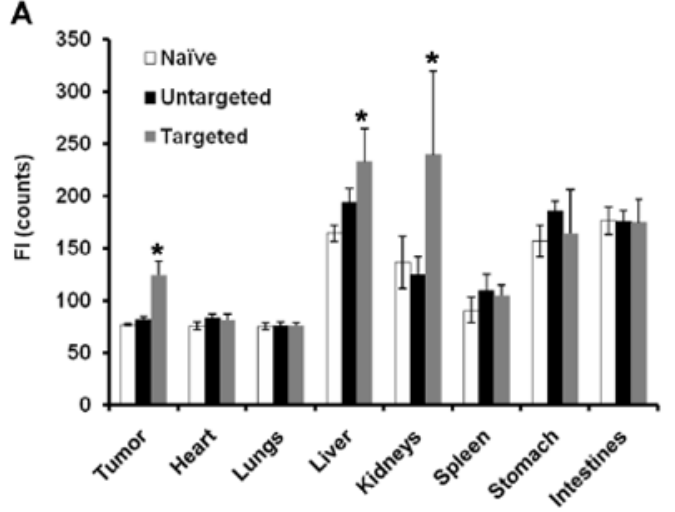

B

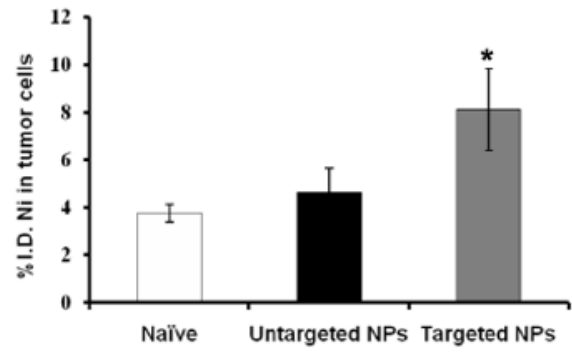

Fig. 5.

(A) Quantitative biodistribution of Alexa750-labeled heptameric $Z^{\text {EGFR }}$ domain targeted NiNPs (IVIS optical imaging) (* indicates p $<0.05$ relative to other groups), (B) Intracellular $\mathrm{Ni}$ accumulation (untargeted and targeted Ni-NPs) in tumor homogenates at $16 \mathrm{~h}$ post i.v. injection (ICP-MS analysis) (* indicates $\mathrm{p}<0.05$ relative to other groups). 


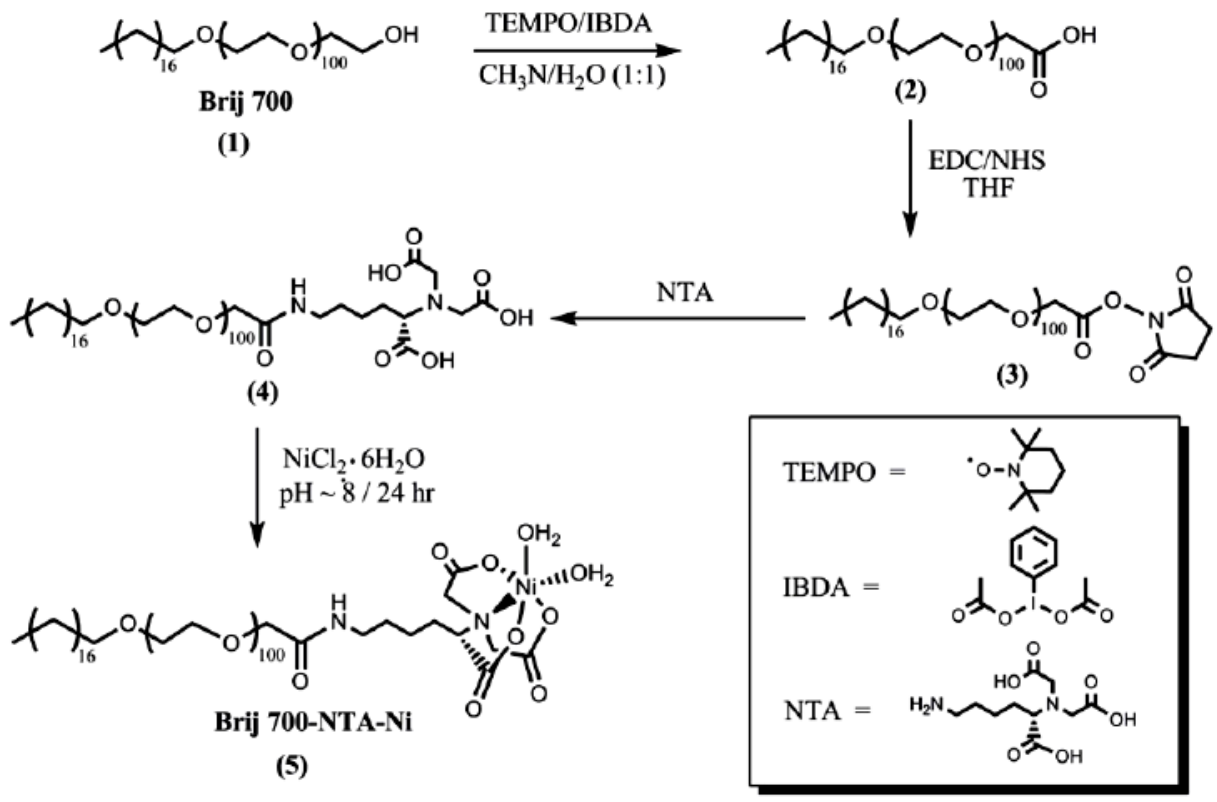

Scheme 1.

Synthesis of Brij 700-NTA-Ni conjugate. 
Table 1

Characterization of Brij 700-NTA-Ni conjugate by ICP-MS analysis.

\begin{tabular}{lllll}
\hline Sample & $\begin{array}{l}\text { Moles of Ni } \\
\text { (Theoretical) }\end{array}$ & Moles of Ni (by ICP-MS) & Moles of Brij700-NTA & $\begin{array}{l}\text { Brij 700-NTA:Ni (by } \\
\text { ICP-MS) }\end{array}$ \\
\hline Brij 700-NTA-Ni Unpurified & $4.05 \times 10^{5}$ & $3.70 \times 10^{5}$ & $2.02 \times 10^{5}$ & $\mathbf{1 . 8 3}$ \\
Brij 700-NTA-Ni Purified & $2.02 \times 10^{5}$ & $2.06 \times 10^{5}$ & $2.02 \times 10^{5}$ & $\mathbf{1 . 0 2}$ \\
\hline
\end{tabular}




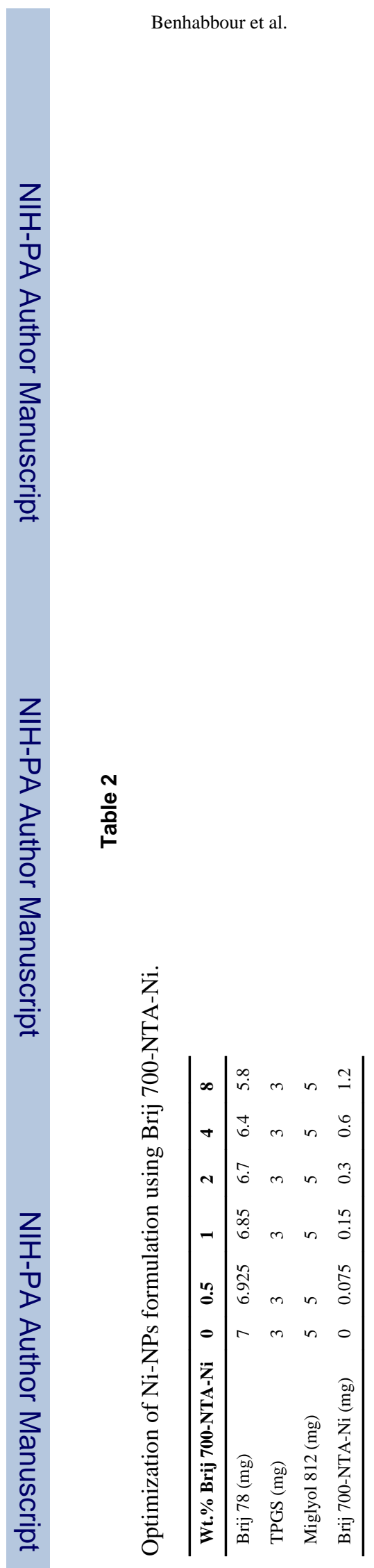

J Control Release. Author manuscript; available in PMC 2013 February 28. 
Table 3

Characterization of various Ni-NPs formulations.

\begin{tabular}{lllll}
\hline Brij 700-NTA-Ni (Wt.\%) & Particle size $^{*}(\mathbf{n m})$ & P.I. $^{*}$ & Zeta potential $^{*}(\mathbf{m V})$ & Ni conc., calc. $(\boldsymbol{\mu M})$ \\
\hline 0 & $207 \pm 1.2$ & $0.14 \pm 0.03$ & $-5.6 \pm 1.8$ & 0 \\
0.5 & $196 \pm 2.9$ & $0.13 \pm 0.02$ & $-12.4 \pm 1.2$ & 3.13 \\
1 & $188 \pm 1.6$ & $0.18 \pm 0.04$ & $-17.6 \pm 1.0$ & 6.25 \\
2 & $191 \pm 4.3$ & $0.28 \pm 0.09$ & $-21.8 \pm 1.6$ & 12.5 \\
4 & $180 \pm 4.2$ & $0.25 \pm 0.10$ & $-20.3 \pm 1.2$ & 25.0 \\
8 & $195 \pm 4.0$ & $0.29 \pm 0.13$ & $-20.9 \pm 0.7$ & 50.0 \\
\hline
\end{tabular}

Data in each group represents mean $\pm \mathrm{SD}(n=3)$. 
Table 4

Percent Ni incorporation within the NPs using Brij 700-NTA-Ni.

\begin{tabular}{llll}
\hline Brij 700-NTA-Ni (wt.\%) & $\boldsymbol{\mu g ~ N i ~ B e f o r e ~ S E C ~}$ & $\boldsymbol{\mu g ~ N i ~ A f t e r ~ S E C ~}^{*}$ & $\boldsymbol{\% ~ N i ~ i n c o r p o r a t e d ~}^{*}$ \\
\hline 0.5 & $2.73 \pm 1.4$ & $0.87 \pm 0.09$ & $32.2 \pm 3.4$ \\
1 & $4.44 \pm 2.4$ & $1.59 \pm 0.26$ & $35.8 \pm 8.4$ \\
2 & $11.7 \pm 3.8$ & $5.59 \pm 0.53$ & $47.8 \pm 2.8$ \\
4 & $18.1 \pm 3.6$ & $8.07 \pm 0.92$ & $44.6 \pm 4.3$ \\
8 & $30.8 \pm 5.8$ & $14.2 \pm 2.23$ & $46.1 \pm 5.7$ \\
\hline * Values reflect amount of Ni per 15 mg of NPs; data in each group represents mean \pm SD $(n=3)$.
\end{tabular}




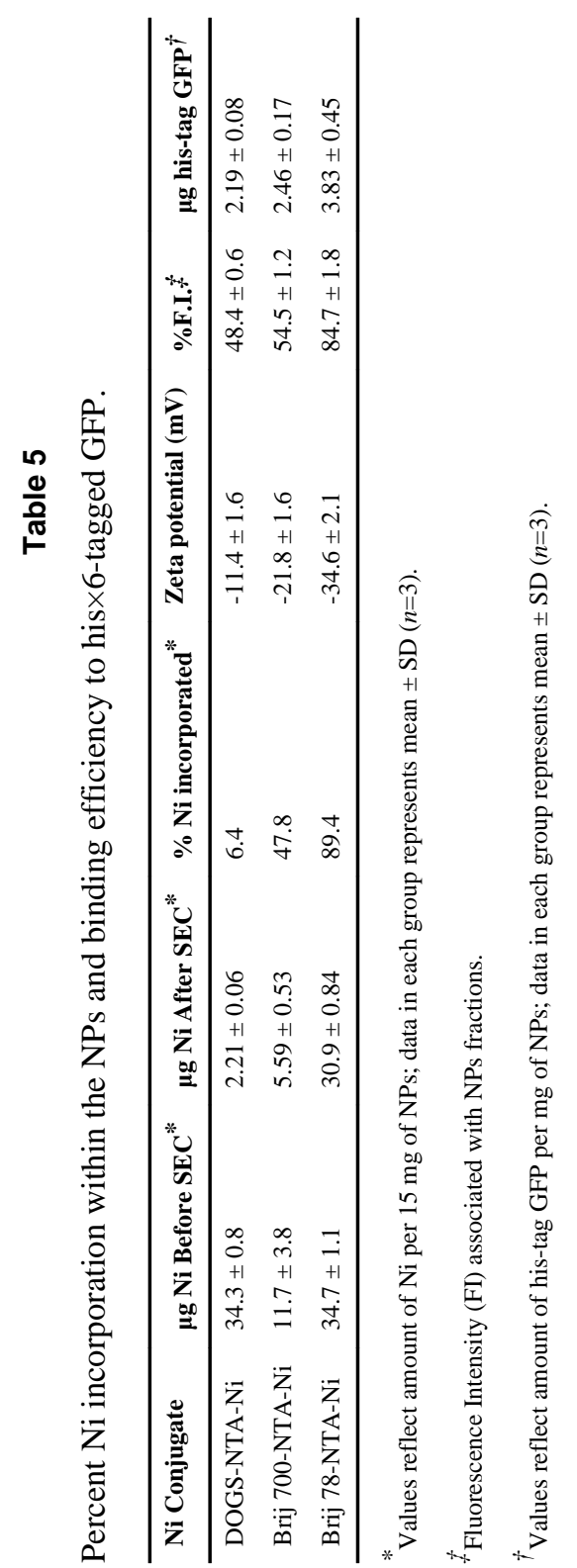


Table 6

Optimization of his $\times 6$-tagged heptamer binding to Ni-NPs.

\begin{tabular}{|c|c|c|c|}
\hline$\mu$ g his $\times 6$-tagged heptamer ${ }^{\dagger}$ & his $\times 6$-tagged heptamer:Ni-NPs ratio (w/w) & $\% \mathbf{F I}^{*}$ & $\mu \mathrm{g}$ his $\times 6$-tagged heptamer ${ }^{\dagger}$ \\
\hline 2.5 & 0.0016 & 92 & 2.3 \\
\hline 3.5 & 0.002 & 95 & 3.3 \\
\hline 5.0 & 0.003 & 81 & 4.1 \\
\hline 10 & 0.007 & 84 & 8.4 \\
\hline 15 & 0.01 & 83 & 12.5 \\
\hline
\end{tabular}

Fluorescence Intensity (FI) associated with NP fractions.

${ }^{\dagger}$ Values reflect amount of his $\times 6$-tagged heptamer per mg of NPs. 


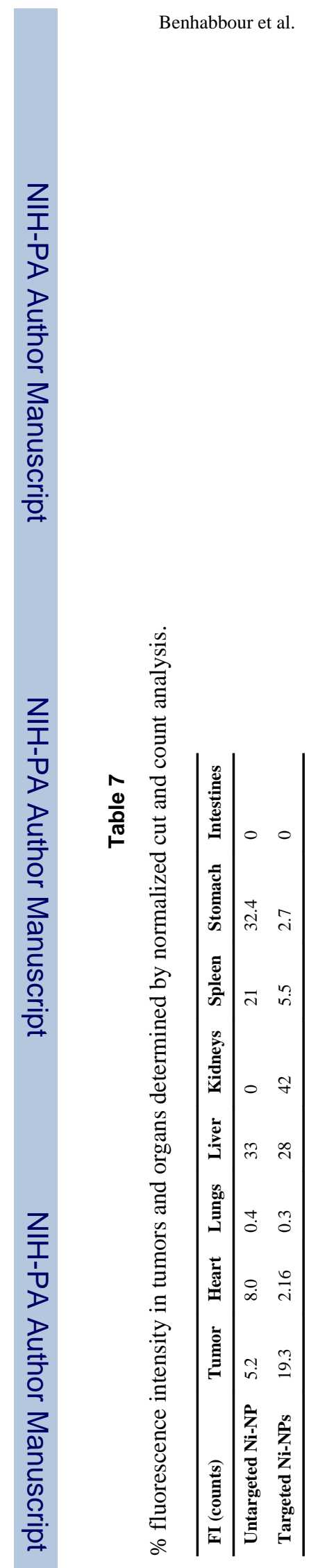

J Control Release. Author manuscript; available in PMC 2013 February 28. 